\title{
Thermal Insulation and R- Value Analysis for Wall Insulated with PCM
}

\author{
K. S. Dhaya Chandhran, M. Jothilakshmi, L. Chandhrkanthamma, A. Mohan
}

\begin{abstract}
At present all the Indians are depending on nonrenewable energy for electricity for house needs. The nature is exploited by this Nonrenewable energy, it scarce fossil fuel source and destroys mother nature. The Air conditioners are devices which is used to reduce the indoor temperature and increases the comfort level. This devices produces greenhouse gases and increasing day by day, which obviously increases Global warming. The medical experts are insisting not to use and expose more to Air conditioners as it stimulates health issues. In order to overcome these problems, an alternate solution to be found and implementing a new method of construction and materials. This is the new attempt by executing a system of cavity wall in a framed structure with circulation of liquid and air in the cavity by embedding the fluted sheets in the exterior walls of the building. The advantage of this system is reducing the thermal conductivity from outside and to reduce the consumption of electricity for air conditioning devices and increases the sustainability of natural sources. Finally the constant-R (Thermal resistivity) value is arrived for composite materials with water.
\end{abstract}

Rundown phrases- Cavity wall, Fluted sheet, Global warming, Green building, Hygrometer, PCM, Thermal envelope.

\section{INTRODUCTION}

There are developments in the promotion of energy efficiency in the construction sector. But in India, rural side individual house constructions are done in conventional method and materials. Due to the low income of the rural and small town people they couldn't afford the air conditioners, but they are the most affected people rather than large town and cities due to global warming.

Air conditioners can use up to 1/6th of India's electricity consumption and on hot summer days it consumes $43 \%$ of the India peak power load. According to the Indian Department of Energy, heating and cooling systems emit over a half billion tons of carbon dioxide into the atmosphere each year, adding to global warming. Because energy is produced from non-renewable sources like coal $44 \%$, petroleum liquids $22 \%$, natural gas $7 \%$,neuclear $1 \%$. They also generate about $24 \%$ of the nations' sulfur dioxide, a chief ingredient in acid rain.

Normal Comfort Zone (for FTA) $23 \pm 1^{\circ} \mathrm{C}, \pm 5 \% \mathrm{RH}, 23^{\circ} \mathrm{C}$ to $25^{\circ} \mathrm{C}$ - all the time. But the environment of many cities in India is very hot in summer due to the major problem of global warming, greenhouse effect and uncertainty in

Revised Manuscript Received on 14 September, 2019.

K. S. Dhaya Chandhran, Easwari engineering college, Department of Civil Engineering, Ramapuram, Chennai, Tamil Nadu, India. (E-mail: civilchandhran@gmail.com)

M. Jothilakshmi, Easwari engineering college, Department of Civil Engineering, Ramapuram, Chennai, Tamil Nadu, India.

L. Chandhrkanthamma, Easwari engineering college, Department of Civil Engineering, Ramapuram, Chennai, Tamil Nadu, India. Engineering, Ramapuram, Chennai, Tamil Nadu, India
A. Mohan, Easwari engineering college, Department of Civil

climatic behavior which is affecting the human beings vastly. This phenomenon affects the village and small towns too. Many literature study shows they are focusing on many materials except water, but it can act as a barrier for thermal conductivity. Our aim is to consider the water to be circulated inside the walls in channels of fluted sheets which acts as a barrier layer, so that thermal conductivity may be reduced/stopped, and also maintain the indoor temperature even there is huge difference in atmosphere temperature.

\section{MATERIALS AND METHODS}

\subsection{Material Selection:}

As this project is to improvise the construction method with least changes in procedure of construction for building types like individual and apartments house buildings(framed), we used the same conventional materials available in local market. Because the masons and labors are quiet familiar with the conventional materials and method. So coarse aggregate, fine aggregate, cement (OPC), clay brick, steel, and water is used as core materials for construction.

The only new material introduced is fluted sheets which are embedded inside the exterior wall. A lot of varieties are available in market, Polypropylene twin wall, multiple wall, corrugated sheets, acrylic sheets, etc.

Introducing a new material should not poses a difficulty in construction and should not increase the thickness of wall as it reduces the floor area, and cost of construction. Our demand and need is something unique, which should accord lot of purposes like thin, hollow, strong, thermal resistance, scratch resistance and space for water circulation. By considering all these requirements we have selected $4 \mathrm{~mm}$ thin polypropylene twin wall fluted sheets with the measurement of $1.83 \mathrm{~m}$ height and $1.21 \mathrm{~m}$ width.

\section{Thermal properties:}

Polygal multiwall polycarbonate can be stable in prolonged service in temperatures ranging from $-40^{\circ} \mathrm{F}$ to $+240^{\circ} \mathrm{F}$. so it can be used as thermal resistive material in building. The thermal resistance factor $\mathrm{R}$-for $4 \mathrm{~mm}$ thick fluted sheet is $1.449 \mathrm{~K} / \mathrm{m}$

\section{Thermal Expansion:}

The coefficient of linear expansion is $6.7 \times 10-5 \mathrm{~m} / \mathrm{m} \cdot{ }^{\circ} \mathrm{C}$. So thermal expansion of Polygal polycarbonate multi wall sheet is $\sim 1 / 4$ " per 4' length and width.
Blue Eyes Intelligence Engineering $\&$ Sciences Publication 


\subsection{Construction procedure}

Selection of site: The construction of model room is selected closer to the conventional building so atmospheric outdoor temperature will be common for the both conventional and model room. Where outdoor temperature will be taken as constant and indoor temperature can be compared. The site is located at medavakkam, Chennai and the coordinate points are $12^{\circ} 54^{\prime} 51.8^{\prime \prime} \mathrm{N}, 80^{\circ} 11^{\prime} 14.3^{\prime \prime} \mathrm{E}$.

The direction of sun in march and April months in Chennai will be 82 to $85^{\prime}$ in the sun rise and 275 to 280 'at the sunset.

\subsubsection{Excavation Work:}

The excavation and depth is decided according to the site conditions, as it is a clay soil, for Isolated footing the depth to be one and half times the width of the Foundation for small low weight constructions. CR Masonry was carried out.

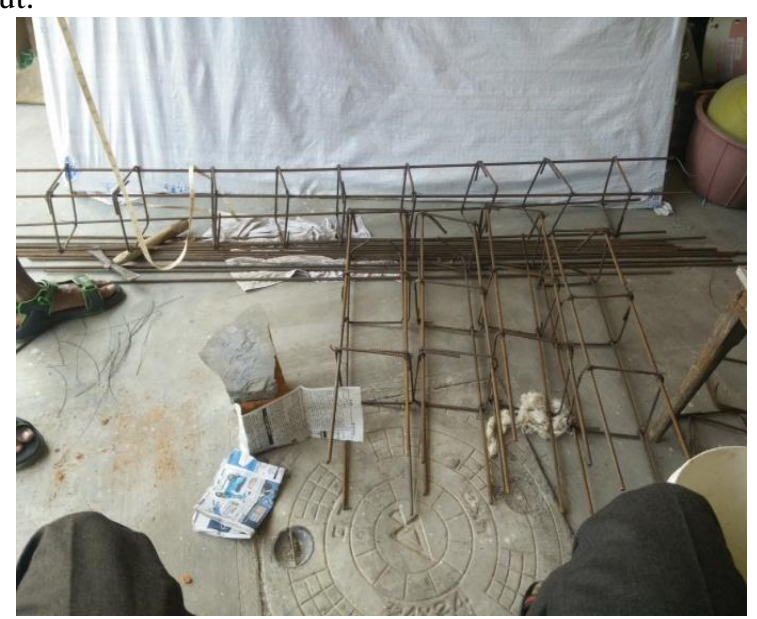

Fig: 2.1: Reinforcement

2.2.2 Procedure to construct foundation and plinth beam:

Concrete in poured in the foundation pit for $150 \mathrm{~mm}$ thick and a column is raised up to plinth level. The plinth level is kept at the ground level itself. The next day concrete is poured in the wooden form work for plinth, mason ensures that it is evenly spread and smoothens out any edges. He also needs to ensure the height of the beam is consistent throughout the periphery. Concrete turned solid within 24hour planks are removed, leaving the beam in it.

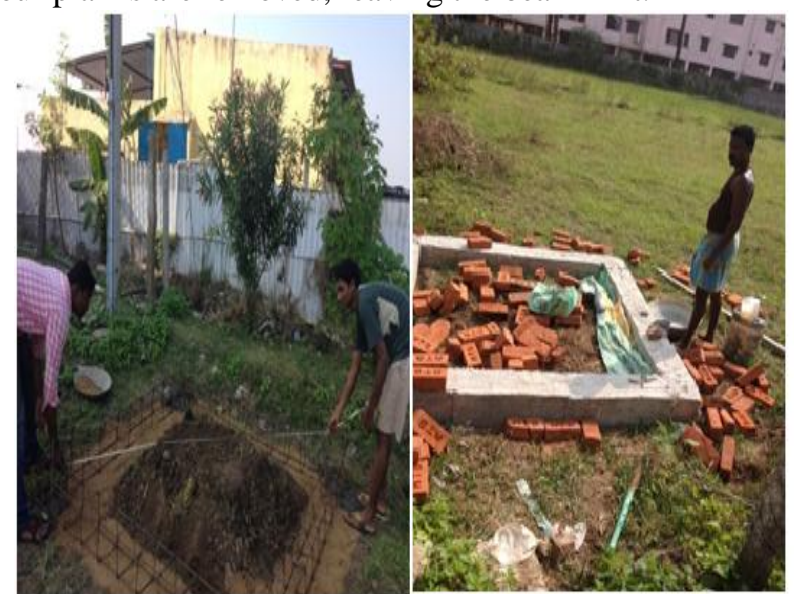

Fig: 2.2. : Placing of reinforcement and construction of plinth beam

\subsubsection{Preparing the Mortar and Laying the Bricks.}

1. We mixed the 1:6 mortar ratios.

2. Here the wall should have capable to attach the fluted sheet. But at the corners of wall we cannot attach the sheets because corners are the load bearing areas for masonry column.

3. So we have decided to provide a strong and cheap column like member at the 4 corner of brick walls.

4. Then for placing of sheets comfortably, we decided to raise the inner half of the wall at first along with the brick pillars as shown in figures 2.4 .

5. As per the procedure we started to erect at the 4 corners of brick pillar along with stretcher bond. $1 / 2$ " is left between each brick for the head joints and the position is marked for the bricks on the bottom layer of brick with a piece of chalk. We Laid this course without cutting any of the bricks. Ties are reinforced as the headers are absence in stretcher bond.

6. We took 2 days for erection of brick column and inner wall. Then we gave 1 day for hardening.

Plastering (Damp proof,10mm thick and water proofing agent is used in the mortar mix) is done for outer side of inner wall to provide smooth finish for fluted sheets and to avoid percolation of moisture content while passing the water through the fluted sheets and smooth surface to avoid damages in sheets while attaching to the wall.

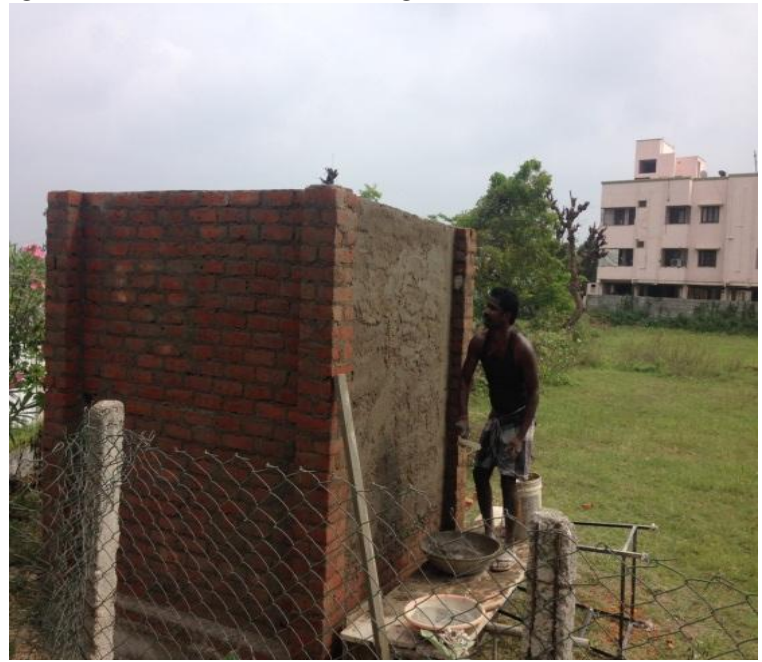

Fig.2.3 Plastering outside of inner wall

2.2.4 Placing the fluted sheets and outer wall construction:

1. The dimension of fluted sheets is $1.83 \mathrm{mX} 1.21 \mathrm{~m}$ and $4 \mathrm{~mm}$ thickness. Then the outer stretcher bond is constructed around the fluted sheets carefully without damaging the sheets.

2. Gutters are provided to collect water at continuous intervals with a brick gap.

3. From the second row/layer normal lying of stretcher bond brick is followed. 


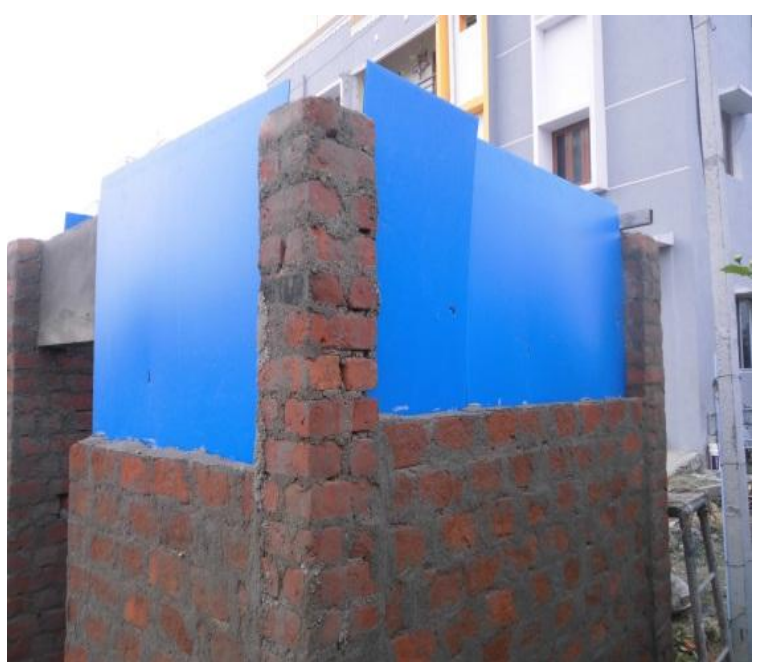

Fig: 2.4 Placing the fluted sheets and Outer-wall construction

\subsubsection{Slab work:}

1. Reinforcement of slab is provided as per the minimum requirements. The excessive part of fluted sheets is Removed (as shown in fig 2.6). The cut portion of fluted sheets is covered with polyethylene sheets to avoid the clogging while concreting the roof. Sides of roof are blocked with wooden boards of 5" width.

2. Concrete mix of M25 is mixed using mixer and additives are added for water resistance.

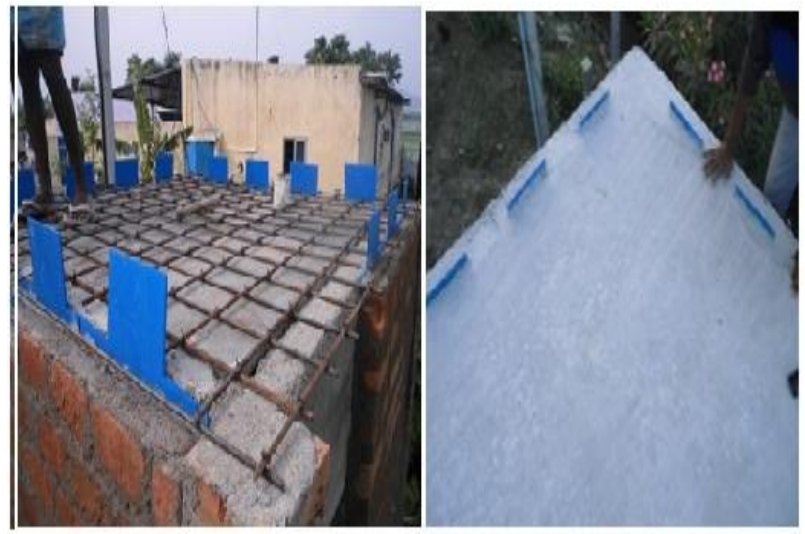

Fig: 2.5 (a) Slab work with fluted sheets projection (b) completion of roof.

\subsubsection{PVC pipelines:}

Normal water is used for circulation through $3 \mathrm{~mm}$ diameter small pipe with holes. Proper pressure is maintained to supply the water properly for all the holes of fluted sheet.

The project is a model so we embedded the fluted sheets in all the 4 walls. An important thing, If the building is planned with orientation, the fluted sheets can be installed for the walls which are perpendicular or inclined to the direction of sun path. So no need of circulation of water for all the outer walls rather than the wall perpendicular or inclined to the direction of sun as the sun direction changes, the water circulation can be changed. So we can avoid the unwanted material, installation and operational charges.

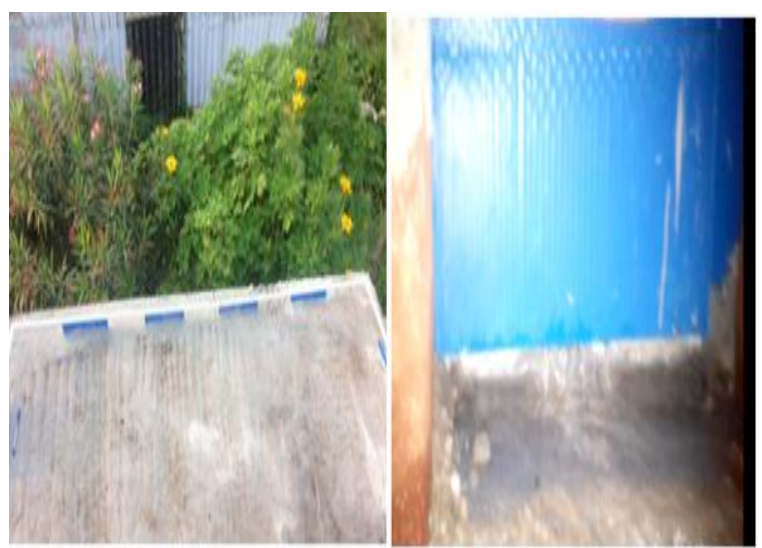

Fig: 2.6: Arrangements of water circulation and flow of water

Normally, thickness of outer brick wall is $220-230 \mathrm{~mm}$, in this project the thickness of the wall is increased $14 \mathrm{~mm}$ (4 $\mathrm{mm}$ fluted sheet and $10 \mathrm{~mm}$ additional intermediate damp proof cement plastering) the work was carried out easily and very effective by the workers.

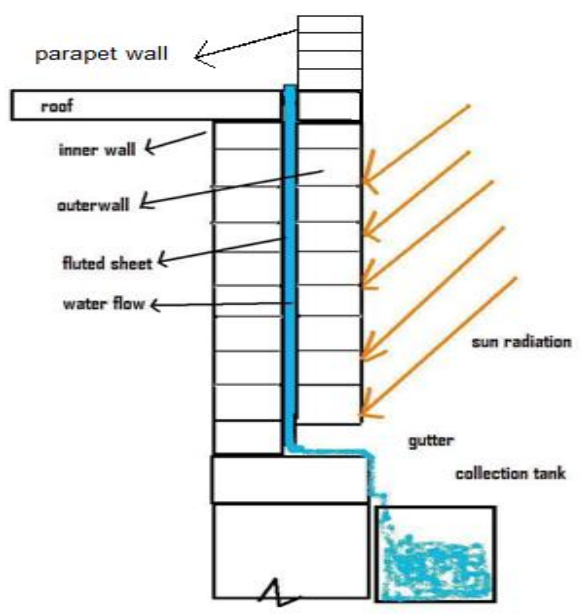

Fig.: 2.7: Schematic representation of the system

\section{RESULTS AND DISCUSSION}

\subsection{Temperature Analysis}

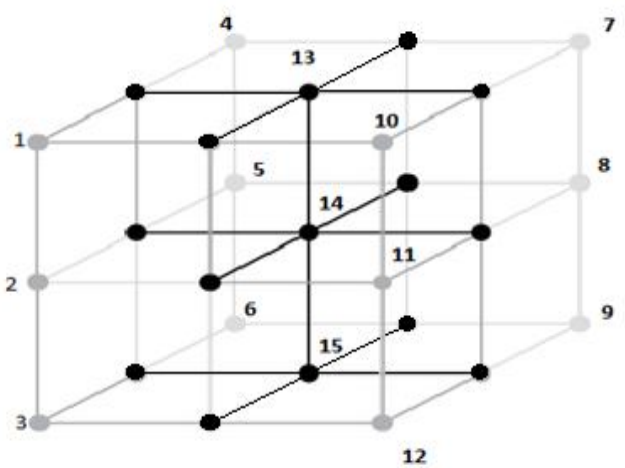

Points of temperature measurement.

Fig: 3.1: Nodal points for temperature analysis in the rooms

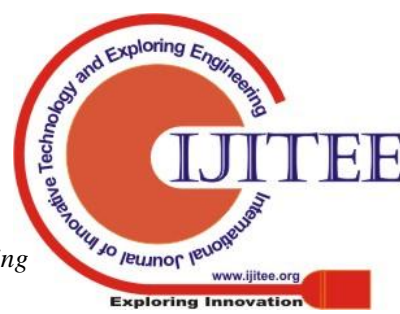


The dark points are the nodal points of the room where temperature and moisture content have been recorded. 15 points has been chosen as the room is $8 \mathrm{~m} 3$ Hygrometer is placed in 15 nodal points of the building as shown in fig 3.1. Temperature difference in each point is noted in the tabular column below. Hygrometer is allowed to settle down for a minute in each point this temperature difference in each point shows us the variance in temperature and humidity in the model building.

These values are compared with the same size of conventional room which is very near to the model room. So we could know that the embedment of the fluted sheets acts as a barrier for conduction of heat through the walls.

These measurements were taken for 45 days, beginning from March1 to April15, 2019, but here we have given only April 14th day's data which has maximum atmospheric temperature measured as 390c.

Water is circulated to the eastern wall from 10:00 am to 12:00 noon and afternoon (12:00 to 5:00 pm we changed the circulation to the western wall. This circulated water is recycled and it was stored in temporary overhead tank. So usage of water will be used only at the required wall against the direct sun direction. Other walls will be having air circulation due to natural wind blow. As it was 390c atmospheric temperature we increased the water circulation time up to 5:00pm. As the hole in supply pipe and fluted sheets are small, we used water droplets as gravity flow inside the fluted sheets. So 2 droplets per second (2drops/second)in each hole we maintained.

Table 3.1: Temperature comparison between conventional $(C) \&$ model $\operatorname{room}(M)$

\begin{tabular}{|c|c|c|c|c|c|c|c|c|c|c|}
\hline $\begin{array}{l}\mathbf{P} \\
\mathbf{O} \\
\mathbf{I} \\
\mathbf{N} \\
\mathbf{T} \\
\mathbf{S}\end{array}$ & \multicolumn{2}{|c|}{$\begin{array}{l}\text { TIME -6 } \\
\text { AM }\end{array}$} & \multicolumn{2}{|c|}{$\begin{array}{l}\text { TIME -10 } \\
\text { AM }\end{array}$} & \multicolumn{2}{|c|}{$\begin{array}{c}\text { TIME -1 } \\
\text { PM }\end{array}$} & \multicolumn{2}{|c|}{$\begin{array}{c}\text { TIME -3 } \\
\text { PM }\end{array}$} & \multicolumn{2}{|c|}{$\begin{array}{c}\text { TIME -6 } \\
\text { PM }\end{array}$} \\
\hline & $C$ & $M$ & $C$ & $M$ & $C$ & $M$ & $C$ & $M$ & $C$ & $M$ \\
\hline 1 & 29 & 28 & 32 & 29 & 34 & $\begin{array}{l}29 . \\
9\end{array}$ & $\begin{array}{l}35 . \\
5\end{array}$ & $\begin{array}{l}29 . \\
1\end{array}$ & 33.2 & 28 \\
\hline 2 & $\begin{array}{l}29 . \\
5\end{array}$ & $\begin{array}{l}27 . \\
3\end{array}$ & $\begin{array}{l}32 . \\
5\end{array}$ & 28 & $\begin{array}{l}34 . \\
5\end{array}$ & $\begin{array}{l}29 . \\
3\end{array}$ & $\begin{array}{l}34 . \\
5\end{array}$ & $\begin{array}{l}28 . \\
5\end{array}$ & 33.5 & $\begin{array}{l}27 . \\
5\end{array}$ \\
\hline 3 & 29 & $\begin{array}{l}27 . \\
2\end{array}$ & 33 & $\begin{array}{l}28 . \\
6\end{array}$ & 34 & 29 & 35 & $\begin{array}{l}28 . \\
6\end{array}$ & 33.4 & $\begin{array}{l}27 . \\
6\end{array}$ \\
\hline 4 & $\begin{array}{l}28 . \\
3\end{array}$ & $\begin{array}{l}27 . \\
9\end{array}$ & $\begin{array}{l}32 . \\
6 \\
\end{array}$ & $\begin{array}{l}28 . \\
9\end{array}$ & 35 & $\begin{array}{l}29 . \\
8\end{array}$ & $\begin{array}{l}35 . \\
9\end{array}$ & $\begin{array}{l}29 . \\
1\end{array}$ & 33.6 & $\begin{array}{l}28 . \\
4\end{array}$ \\
\hline 5 & $\begin{array}{l}29 . \\
1\end{array}$ & $\begin{array}{l}27 . \\
5\end{array}$ & $\begin{array}{l}32 . \\
8\end{array}$ & $\begin{array}{l}28 . \\
4\end{array}$ & 35 & $\begin{array}{l}29 . \\
4\end{array}$ & $\begin{array}{l}35 . \\
4\end{array}$ & $\begin{array}{l}28 . \\
1\end{array}$ & 33.33 & $\begin{array}{l}27 . \\
8\end{array}$ \\
\hline 6 & $\begin{array}{l}28 . \\
3\end{array}$ & $\begin{array}{l}27 . \\
2\end{array}$ & $\begin{array}{l}32 . \\
5\end{array}$ & $\begin{array}{l}28 . \\
5\end{array}$ & $\begin{array}{l}34 . \\
9\end{array}$ & $\begin{array}{l}29 . \\
5\end{array}$ & $\begin{array}{l}35 . \\
8\end{array}$ & $\begin{array}{l}28 . \\
6\end{array}$ & 33.3 & $\begin{array}{l}27 . \\
1\end{array}$ \\
\hline 7 & $\begin{array}{l}28 . \\
5\end{array}$ & 28 & $\begin{array}{l}32 . \\
6\end{array}$ & 29 & $\begin{array}{l}34 . \\
8\end{array}$ & $\begin{array}{l}29 . \\
8\end{array}$ & $\begin{array}{l}35 . \\
2\end{array}$ & $\begin{array}{l}29 . \\
8\end{array}$ & 33.4 & $\begin{array}{l}28 . \\
1\end{array}$ \\
\hline 8 & $\begin{array}{l}29 . \\
6\end{array}$ & $\begin{array}{l}27 . \\
3\end{array}$ & 32 & $\begin{array}{l}28 . \\
6\end{array}$ & 34 & $\begin{array}{l}28 . \\
5\end{array}$ & $\begin{array}{l}34 . \\
9\end{array}$ & $\begin{array}{l}28 . \\
3\end{array}$ & 33.5 & $\begin{array}{l}27 . \\
5\end{array}$ \\
\hline 9 & 29 & $\begin{array}{l}27 . \\
2\end{array}$ & 33 & $\begin{array}{l}28 . \\
5\end{array}$ & 35 & $\begin{array}{l}29 . \\
4\end{array}$ & $\begin{array}{l}35 . \\
2\end{array}$ & $\begin{array}{l}28 . \\
5\end{array}$ & 33.6 & $\begin{array}{l}27 . \\
5\end{array}$ \\
\hline 10 & $\begin{array}{l}28 . \\
7\end{array}$ & $\begin{array}{l}27 . \\
7\end{array}$ & $\begin{array}{l}33 . \\
1\end{array}$ & $\begin{array}{l}29 . \\
1\end{array}$ & 35 & $\begin{array}{l}29 . \\
9\end{array}$ & $\begin{array}{l}35 . \\
7\end{array}$ & 29 & 33.9 & $\begin{array}{l}28 . \\
2\end{array}$ \\
\hline 11 & 29 & $\begin{array}{l}27 . \\
2\end{array}$ & $\begin{array}{l}32 . \\
9\end{array}$ & 28 & $\begin{array}{l}34 . \\
9\end{array}$ & $\begin{array}{l}28 . \\
9\end{array}$ & $\begin{array}{l}35 . \\
6\end{array}$ & $\begin{array}{l}28 . \\
6\end{array}$ & 33.4 & $\begin{array}{l}27 . \\
4\end{array}$ \\
\hline 12 & 28 & 7.3 & 32 & $\begin{array}{l}28 . \\
3\end{array}$ & $\begin{array}{l}34 . \\
6\end{array}$ & 29 & $\begin{array}{l}35 . \\
4\end{array}$ & $\begin{array}{l}28 . \\
5\end{array}$ & 34.1 & $\begin{array}{l}27 . \\
2\end{array}$ \\
\hline & & $\begin{array}{l}\mathrm{Co} \\
\mathrm{Mc}\end{array}$ & el 1 & & C & & & & & \\
\hline
\end{tabular}

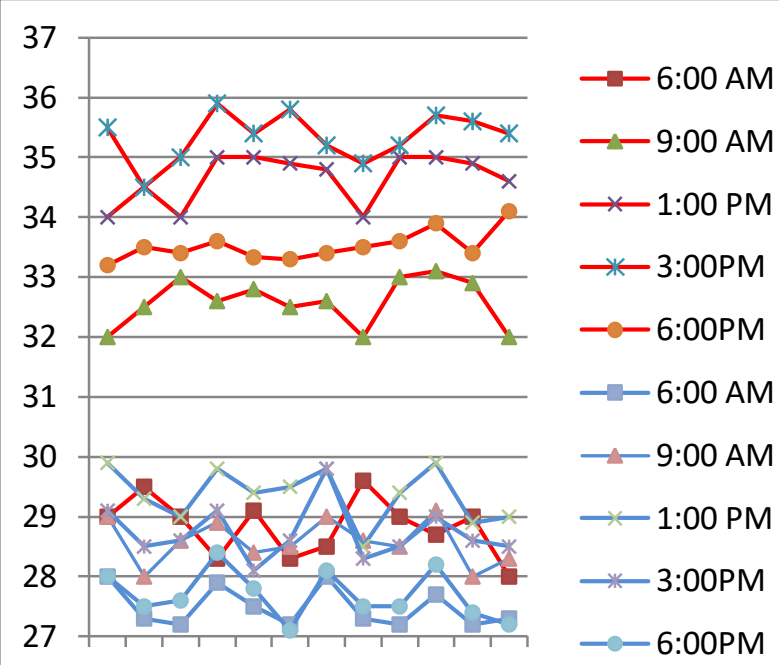

1223445667889101112

Fig: 3.2Temperature comparison between conventional \& model room

Table 3.2: Moisture content comparison between conventional \& model room

\begin{tabular}{|c|c|c|c|c|c|c|c|c|c|c|}
\hline & \multicolumn{5}{|c|}{ Conventional } & \multicolumn{5}{|c|}{ Model } \\
\hline $\begin{array}{l}\text { Po } \\
\text { int } \\
s\end{array}$ & $\begin{array}{l}6: 0 \\
0 \\
A \\
M\end{array}$ & $\begin{array}{l}9: 0 \\
0 \\
A \\
M\end{array}$ & $\begin{array}{l}1: 0 \\
0 \\
P \\
M\end{array}$ & $\begin{array}{l}3: 0 \\
0 P \\
M\end{array}$ & $\begin{array}{l}6: 0 \\
0 \\
A \\
M\end{array}$ & $\begin{array}{l}6: 0 \\
0 \\
A \\
M\end{array}$ & $\begin{array}{l}9: 0 \\
0 \\
A \\
M\end{array}$ & $\begin{array}{l}1: 0 \\
0 \\
P \\
M\end{array}$ & $\begin{array}{l}3: 0 \\
0 P \\
M\end{array}$ & $\begin{array}{l}6: 0 \\
0 P \\
M\end{array}$ \\
\hline 1 & 67 & 65 & 50 & 60 & 86 & 68 & 40 & 38 & 40 & 55 \\
\hline 2 & 68 & 54 & 60 & 64 & 88 & 69 & 45 & 40 & 42 & 56 \\
\hline 3 & 67 & 55 & 55 & 68 & 84 & 67 & 42 & 42 & 41 & 54 \\
\hline 4 & 66 & 64 & 52 & 62 & 82 & 68 & 46 & 46 & 47 & 53 \\
\hline 5 & 67 & 68 & 61 & 65 & 88 & 66 & 41 & 41 & 42 & 55 \\
\hline 6 & 65 & 69 & 55 & 66 & 86 & 67 & 42 & 42 & 46 & 52 \\
\hline 7 & 66 & 64 & 52 & 61 & 82 & 68 & 46 & 46 & 45 & 57 \\
\hline 8 & 67 & 71 & 58 & 65 & 87 & 69 & 45 & 45 & 43 & 56 \\
\hline 9 & 68 & 72 & 54 & 69 & 88 & 66 & 41 & 41 & 47 & 54 \\
\hline 10 & 65 & 64 & 54 & 60 & 80 & 65 & 43 & 43 & 48 & 53 \\
\hline 11 & 65 & 69 & 55 & 68 & 85 & 63 & 44 & 44 & 41 & 57 \\
\hline 12 & 62 & 68 & 56 & 64 & 86 & 64 & 41 & 41 & 44 & 56 \\
\hline
\end{tabular}

\begin{tabular}{|c|c|c|c|c|c|}
\hline $\begin{array}{c}\text { Method } \\
\text { s of } \\
\text { cooling }\end{array}$ & $\begin{array}{c}\text { Capacit } \\
\text { y per } \\
\text { hour }\end{array}$ & $\begin{array}{c}\text { running } \\
\text { per day } \\
\text { (6hours } \\
\text { ) }\end{array}$ & $\begin{array}{c}\text { Total } \\
\text { amou } \\
\mathrm{nt} \\
\text { per } \\
\text { month }\end{array}$ & $\begin{array}{c}\text { Rate } \\
\text { per } \\
\text { unit in } \\
\text { rupees }\end{array}$ & $\begin{array}{c}\text { Total cost } \\
\text { per month } \\
\text { in rupees }\end{array}$ \\
\hline A/C & $\begin{array}{c}1.5 \\
\text { tones }\end{array}$ & $9 \mathrm{~kW}$ & $\begin{array}{c}270 \\
\mathrm{~kW}\end{array}$ & 3.00 & 810.00 \\
\hline $\begin{array}{c}\text { Fluted } \\
\text { sheets } \\
\text { with } \\
\text { running } \\
\text { water/3 } \\
\text { metre } \\
\text { length }\end{array}$ & $\begin{array}{c}0.072 \\
\mathrm{~m}^{3} \times 3= \\
0.216 \\
\mathrm{~m}^{3}\end{array}$ & 0.00706 & 0.212 & 3.00 & $0.6358 \sim 1.0$ \\
$\mathrm{k} \mathrm{W}$ & & & & 0 \\
\hline
\end{tabular}




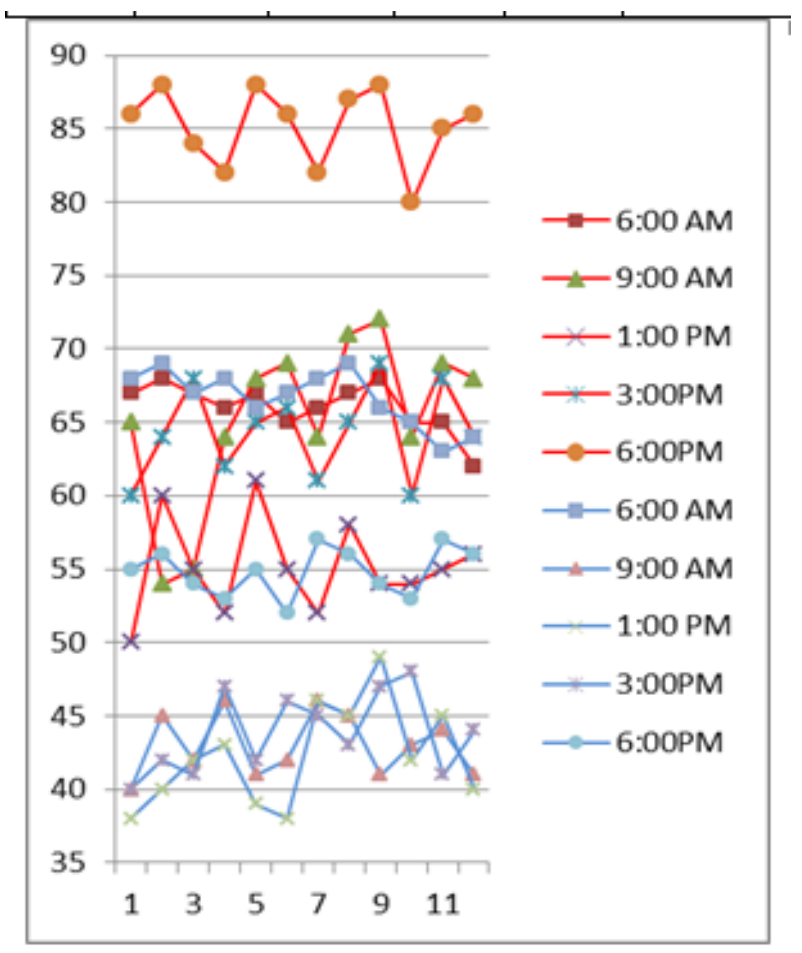

Fig: 3.3 Moisture content comparison between conventional \& model room

\section{DISCUSSION ON RESULTS:}

\subsection{Discussion on temperature:}

The measurements of indoor temperature of conventional room and model room embedded with fluted sheets are compared. This comparison helps to identify the difference in temperature. That, the model room maintains the room temperature around $280 \mathrm{c}(+/-20 \mathrm{c})$ and moisture content between $52 \%$ to $88 \%$, even the maximum atmospheric temperatures 390c, the temperature is 100c lesser and moisture content is $25 \%$ averagely lesser than conventional room. This is due to the circulation of water, which acts as a barrier for thermal conductance. Water used for circulation is recycled water. So this will reduce the usage of air conditioner and ultimately reduces the power consumption.

Even in May and June months outdoor temperature may will raise to $400 \mathrm{c}$ and above this water circulation controls and avoids the conduction of heat through the walls, even outer wall's outer surface observes and retains it cannot conduct it to the inner wall. So the inner wall temperature will be always maintained in average temperature. Only through the opening of walls like door and windows the temperature can be transported through the air circulation and heat radiation.

\subsection{Discussion on humidity:}

Relative humidity of a human being should be $25 \%$ to 60 $\%$, which is nor hot dry either wet. As the results show that the model room maintains the humidity range between $50 \%$, to $90 \%$, the fig:3.3 shows at 1:00PMthe humidity in the model room is not below than $50 \%$ and where conventional room has $37 \%$ even the outdoor temperature is just above $350 \mathrm{c}$. If the atmosphere temperature rises more than $400 \mathrm{c}$, this relative humidity may fall below the comfort range for conventional room where it will not go down below the $25 \%$ comfort range for model room.

In overall comparison the difference between model room and conventional room is $20 \%$. So this new method helps to maintain the humidity between $50 \%$ to $90 \%$.at

Quantity of water used for circulation.

Even we used recycled water for circulation; it needed electricity power for storing in overhead tank. So calculating the quantity of circulating water and power is important for comparing the energy consumed and energy saved by this system, which can be concluded for sustainable development.

We computed the quantity of water circulated and power used, based on our system. We considered $100 \%$ efficiency for pumps as the head is just $2 \mathrm{~m}$ from our sump.

2 droplets of water for 1 hole per second.1droplet is $0.05 \mathrm{ml}$ of water.

Quantity $=0.1 \mathrm{ml} / \mathrm{sec}$ per hole $=0.1 \times 3600 \mathrm{ml} / \mathrm{hr}$ $=0.360 \mathrm{lt} / \mathrm{hr}$ per hole

So $1 \mathrm{~m}$ of fluted sheets has 200 holes. So total quantity for $1 \mathrm{~m}$ running length is

Total Quantity $=200 \times 0.36=72 \mathrm{lts} / \mathrm{hr}=0.072 \mathrm{~m} 3 / \mathrm{hr}$

Energy spent for storing in overhead $\operatorname{tank}(2 \mathrm{~m}$ head $)$ :

$\mathrm{Ph}(\mathrm{kW})=\mathrm{Q} X \rho \times \mathrm{g} \times \mathrm{H} /(3.6 \times 106)$

$$
\begin{array}{ll}
\mathrm{P}(\mathrm{kW}) & =(0.072 \times 1000 \times 9.81 \times 2) /\left(3.6 \times 10^{\wedge} 6\right) \\
\mathrm{P} & =0.0003924 \mathrm{kWh}
\end{array}
$$

Suppose if the water circulation takes place for $6 \mathrm{hrs}$ per day, then

$$
\mathrm{P} \quad=0.002354 \mathrm{~kW} \text { per } 6 \text { hours per day }
$$

For our $2 \mathrm{~m} \times 2 \mathrm{~m}$ sized model room and $1.8 \mathrm{~m}$ running length of fluted sheet.

$$
\mathrm{P} \quad=0.004237 \mathrm{~kW},
$$

$\mathrm{P} \quad=0.004237 \times 30=0.127 \mathrm{~kW}$ per month for

1.8 metre running length.

So, total electricity used for one month of operation is $0.13 \mathrm{~kW}$.

If The project it for $9 \mathrm{~m}^{2}$ sized room $(3 \mathrm{mX} 3 \mathrm{~m})$ have 1.5 ton $\mathrm{A} / \mathrm{C}$ device, and $3 \mathrm{~m}$ running length of fluted sheet

Table 3.3: Cost comparison between $\mathrm{A} / \mathrm{C} \&$ water circulation fluted sheet for $3 \mathrm{~m} \times 3 \mathrm{~m}$ room

So 1250 times lesser in operational cost compared with $\mathrm{A} / \mathrm{C}$.

\section{$R$-Value Calculation:}

The temperature resistance value of this composite wall is $R=R$ value of 4 " Brick walls $+R$ value of fluted sheets $+R$ value of the Cement Mortar+ $R$ value of the water flow.

$\mathrm{R}$ value of 4 " Brick walls( Inner and outer)

$$
=0.8 \times 2=1.6 \mathrm{~m} 2 \mathrm{~K} / \mathrm{W}
$$

$\mathrm{R}$ value of fluted sheet $4 \mathrm{~mm}$ thick $=\quad 1.5 \mathrm{~m} 2 \mathrm{~K} / \mathrm{W}$

$\mathrm{R}$ value of the cement mortar $\quad=0.1 \mathrm{~m} 2 \mathrm{~K} / \mathrm{W}$ for $1 / 2$ " thick

$$
\mathrm{R} \text { value of water } \quad=1.72 \mathrm{~m} 2 \mathrm{~K} / \mathrm{W}
$$

$\mathrm{R}=1.6+1.5+0.1+1.72=4.92 \mathrm{~m} 2 \mathrm{~K} / \mathrm{W}$ (Including Water)

$\mathrm{R}=1.6+1.5+0.1=3.3 \mathrm{~m} 2 \mathrm{~K} / \mathrm{W}$ (Excluding water floor)

But our thermal resistance value may be increased above the $4.92 \mathrm{~m} 2 \mathrm{~K} / \mathrm{w}$ while the water is circulated.

The calculated $R$ value is an unique which is not adopted anywhere in the composite material construction. 


\section{Discussion on Cost estimation comparison:}

As the cost of the construction increases about INR $100 /$ square meter. That is 3-4\% increase in the construction cost of conventional brick wall construction. Paybackperiod will be Four To Six Months itself.

\section{CONCLUSION}

The novelty of this research is to reduce the electricity in residential buildings by reducing the usage air conditioning systems. Fluted sheets with circulation of air and water embedded inside the outer wall is the first attempt in the world, which is utilizing the running water as a barrier layer for heat conduction from the sun and acts as thermal envelope. This water circulation and air circulation decreases the thermal conductivity and maintains the indoor room temperature between $270 \mathrm{c}$ to $290 \mathrm{c}$ as the conventional room temperature fluctuates from $280 \mathrm{c}$ to $350 \mathrm{c}$ in daytime. So using this new method of construction and system, have reduced the indoor room temperature about 70c than conventional type room. As the comfort temperature for human being is 230c, the model room is closer than the conventional room. This composite wall $\mathrm{R}$ value is 4.92 which is distinctive in the composite materials wall construction.

If this system is adapted, it costs 1250 times lesser for operational cost compared with air conditioners, the usage of electricity which is produced from fossil fuels will be reduced ultimately, and the sustainability of nonrenewable sources can be prolonged in India.

\section{REFERENCES}

1. Ben Williams (2005) from de la sale college, Malvern Ventilation and Infiltration chapter, Fundamentals volume of the ASHRAE Handbook, ASHRAE, Inc., Atlanta, GA,

2. Gail Schiller Brager, Ph.D., (2000) member ASHRAE, A standard for natural ventilation.

3. Hook T (2009) The Flemish Institute for Technological Research (VITO) in association with the Wuppertal Institute for Climate, Environment and Energy (WIKUE).

4. James William (2010) Report for the European Commission - DG Environment by AEA, Harwell, June

5. Pauschinger T. (2012) Solar District Heating with Seasonal Thermal Energy Storage in Germany. European Sustainable Energy Week, Brussels.

6. Raad Z Homod, (2010) Department of Mechanical Engineering, University of Basrah, Qarmat Ali Campus, Basrah.

7. Rezaie B., Rosen M.A. (2012) District heating and cooling: Review of technology and potential enhancements. Applied Energy (1) Green Energy; (2)Special Section from papers presented at the 2nd International Energy 2030 Conf. 93:0:pp.

8. RinkutaurandvidyadeviT (2009) Cavity walls, TCE Consulting Engineers Ltd, New Delhi.

9. Robert L. (2011) Tazelaar ,current trends in low-energy HVAC design, PE, LEED AP.

10. U.S Energy information administration international energy agency, 2012

11. www.en.wikipedia.org/wiki/Electricity_sector_in_India

12. www.en.wikipedia.org/wiki/Room_temperature

13. www.indiaenergy.gov.in/demand_homelight.php

14. www.engineeringtoolbox.com/relative-humidityd_895.html

\section{AUTHORS PROFILE}

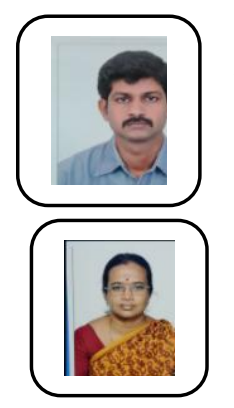

\section{K. S. DHAYA CHANDHRAN,}

Assistant professor, department of civil engineering, Easwari engineering college, Chennai. civilchandhran@gamil.com

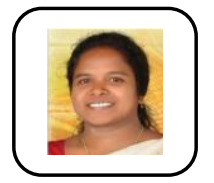

M. JOTHILAKSHMI ,

Assistant professor, department of civil engineering, $\quad$ Easwari engineering college, Chennai. jothisatya07@gamil.com

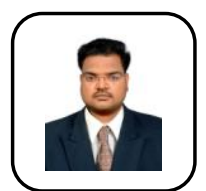

\section{CHANDHRKANTHAMMA \\ Assistant professor, department of civil engineering, Easwari engineering college, Chennai meetchandrakantha@gamil.com}

\section{A MOHAN}

Assistant professor, department of civil engineering, Easwari engineering college, Chennai. mohananbarasu@gamil.com 